\title{
VARIATION IN DISTRIBUTION, MORPHOLOGY AND CALLING SONG OF TWO POPULATIONS OF PTEROPHYLLA CAMELLIFOLIA (ORTHOPTERA: TETTIGONIIDAE) ${ }^{1}$
}

\author{
By Robert C. North ${ }^{2}$ and Kenneth C. Shaw \\ Department of Zoology \\ Iowa State University \\ Ames, Iowa 50011
}

\section{INTRODUCTION}

There are more than 200 species of singing katydids, crickets, and cicadas in the eastern United States. Among these, Pterophylla camellifolia (Fabricius) is unique in that several populations, identifiable by differences in song and morphology, are separated by zones of intergradation (Alexander 1968). This unique situation is associated with a history of taxonomic confusion.

Fabricius (1775) described two species of the genus Locusta: camellifolia and perspicillatus. L. camellifolia (female specimen) was described in the sentence preceding $L$. perspicillatus (male specimen). Subsequently, Kirby and Spence (1828) placed camellifolia and perspicillatus in the genus Pterophylla. Burmeister (1838) placed perspicillatus within the new genus Cyrtophyllus. Caudell (1906) divided Cyrtophyllus into three genera, Cyrtophyllus, Paracyrtophyllus and Lea, and described three new species of Cyrtophyllus: elongatus, furcatus and intermedius, as well as retaining perspicillatus. Kirby (1906) synonymized Cyrtophyllus with Pterophylla. Rehn and Hebard (1916) combined Caudell's $C$. perspicillatus and elongatus into Pterophylla camellifolia camellifolia, and C. intermedius became P. camellifolia intermedia. Hebard (1941) recognized two species of Pterophylla, camellifolia and furcata, with camellifolia divided into three subspecies (P. c. camellifolia, $P$. c. intermedia, and P. c. dentifera) and furcata into two subspecies ( $P$. f. furcata, and $P$. f. laletica). Hebard believed there were racial differences among specimens col-

\footnotetext{
${ }^{1}$ Part of a thesis submitted by the first author to the Graduate College, Iowa State University, in partial fulfillment of the requirements for the degree of Master of Science, June 1978.

${ }^{2}$ Present address: Department of Entomology, Iowa State University, Ames, Iowa 50011.

Manuscript received by the editor February 22, 1980
} 
lected from the northern (Pennsylvania to Virginia), southern (South Carolina to Florida), and southwestern (Oklahoma, Arkansas, southwest Missouri) ranges of $P$. c. camellifolia. Apparent intergradation of subgenital plate dimensions, along with similar appearance of male cerci in southeastern material and specimens from Pennsylvania, precluded his recognizing these three populations as subspecies.

Alexander (1956) noted that specimens from Ohio and North Carolina differ in the shape of the male subgenital plate and pulse rate of the calling sound. Subsequently, on the basis of these differences, Alexander and Shaw (unpublished) differentiated three populations. Two of these probably correspond to Hebard's (1941) northern and southern populations of $P$. c. camellifolia. A third population, whose geographic distribution has not been determined in detail, occurs in Louisiana, Mississippi, southwestern Georgia and probably Tennessee. On the basis of intergradation in calling sound parameters (pulse rate and chirp pulse number), and subgenital plate dimensions, Alexander and Shaw hypothesized a zone of hybridization, forming an inverted Y-shape, among the three populations (Alexander 1968).

Shaw and Carlson (1969) used differences in chirp length of calling sounds and length of male subgenital plate to distinguish two populations of $P$. camellifolia in Iowa. For one population, representing the westward extension of the northern population of Alexander and Shaw, they reported subgenital plate lengths of 11.8 to $13.2 \mathrm{~mm}$ and two- to three-pulse chirps. A previously unreported western population in Iowa possesses subgenital plates 14.7 to $16.8 \mathrm{~mm}$ in length and chirps of 8 to 15 pulses.

Shaw and Carlson's (1969) characterization of the two populations of $P$. camellifolia was based on relatively little data; namely, song records from three counties (Boone, Hardin, Story), and subgenital plate measurements from 13 specimens representing seven counties (Boone, Hardin, Linn, Marion, Story, Van Buren, Worth). Since this publication we have been unable to confirm two of the geographic locations of western P. camellifolia based on subgenital plate measurements of specimens in the Iowa State University insect collection. Several visits to Worth County failed to uncover any P. camellifolia in this northern county. We have heard only northern males singing in Van Buren County in southeast Iowa. 
This study is a detailed analysis of the geographic distribution of $P$. camellifolia in Iowa and a more extensive characterization of population differences based upon both behavioral (parameters of male calling sounds) and morphological characters.

\section{Methods}

We determinted the distribution of $P$. camellifolia in Iowa during the summers of 1975-1978. Colonies (disjunct groups of katydids) were located by driving at reduced speeds along rivers and stopping at approximately $1 / 2 \mathrm{~km}$ intervals to listen for the loud choruses of calling sounds. Forest preserves and state and county parks were also surveyed throughout the state.

Surveys in 1975 and 1976 indicated that northwestern and north central Iowa, areas with relatively little forested lands, were void of $P$. camellifolia. These surveys, as well as records of previous investigators (Froeschner 1954, Shaw and Carlson 1969), suggested that an extensive survey of gallery forests along certain rivers, e.g., Cedar, Des Moines, Iowa, Racoon, Skunk, in central, southern, and eastern Iowa would be most productive. During the surveys, exact locations of katydid colonies were recorded on county maps. Other data taken included: 1) written records of chirp pulse numbers from 10 to 20 katydids per colony, 2) tape recordings of calling sounds for 5 to 10 katydids per colony, and 3) collection of specimens whenever possible.

P. camellifolia is a large, flightless, green katydid that resides near the tops of tall trees in oak-hickory forests. Males stridulate only at night and in Iowa this takes place from the last of July until the first or second frost in October. Thus, it was necessary to locate the calling male in a tree, climb the tree, spot the katydid with a light, and capture it by hand.

Calling sounds were recorded on a Nagra III tape recorder. An American electrodynamic microphone (Model D33) mounted in a 38 $\mathrm{cm}$ aluminum parabolic reflector allowed recordings of individual katydids. Ambient temperature was taken at the site of each tape recording.

Pulse rate was determined from audiospectrograms made with a sonagraph (Kay Vibralyzer). Pulse intervals and lengths were determined to the nearest 0.01 second. 


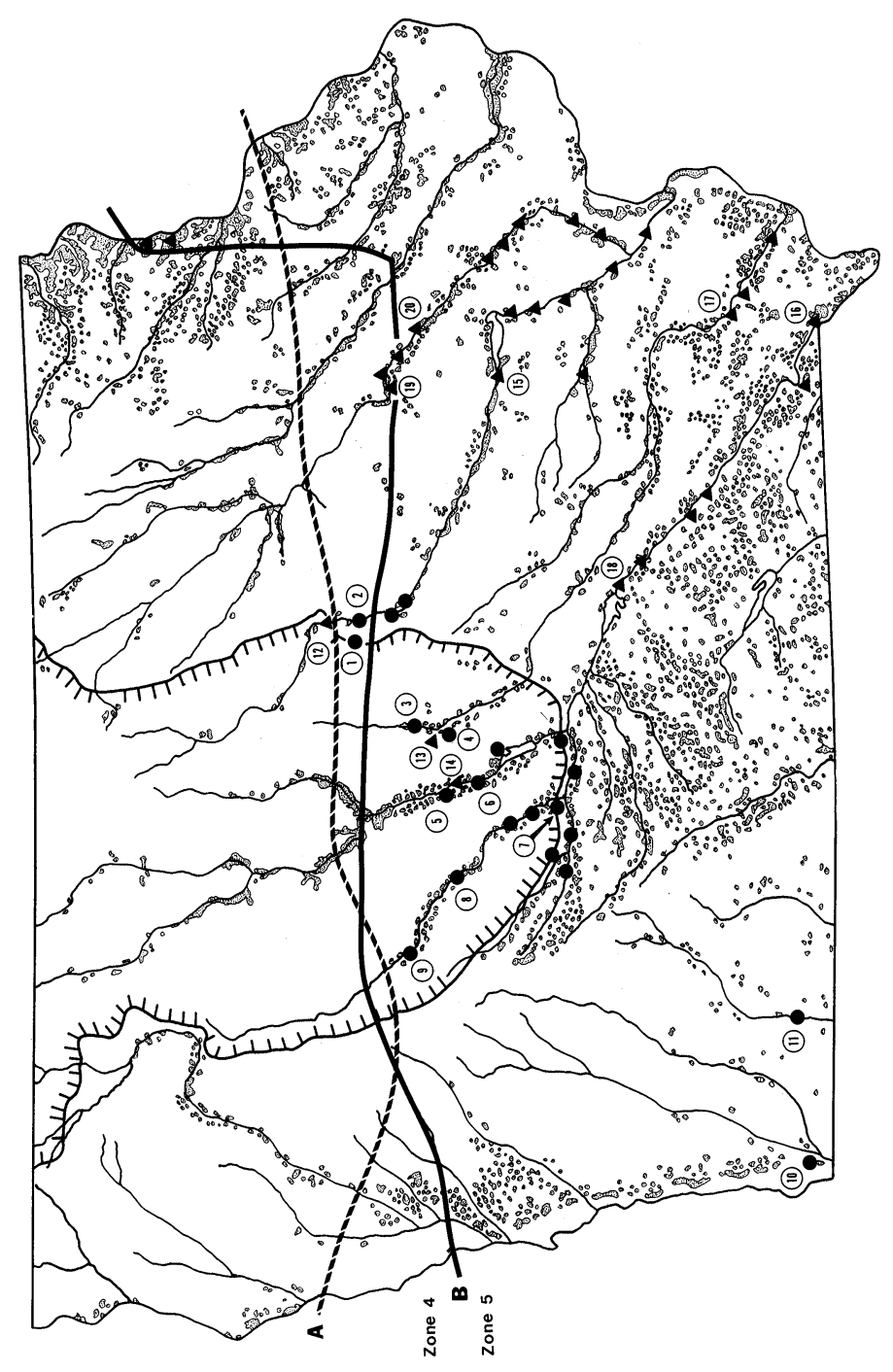

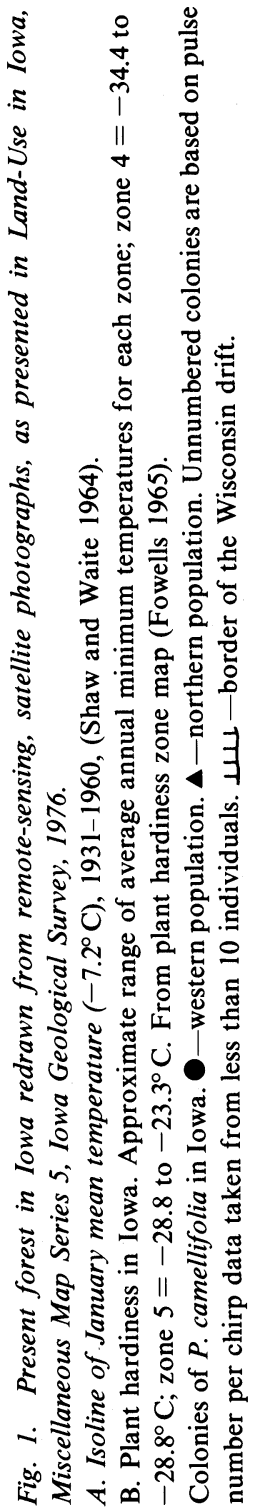


Morphological characters were determined from 13 previously collected specimens and from 192 males collected from 15 different colonies in 1977 and 1978. We examined characters used previously: length of body, length of metathoracic femur, length and width of tegmina, length and width of subgenital plate, length of the subgenital plate slit, and shape of cerci (Beutenmuller 1894, Caudell 1906, Blatchley 1903, 1920, Walden 1911, Hebard 1941, Shaw and Carlson 1969). In addition we measured the distance from the frons to the distal end of the tegmina. Measurements were made with calipers and an ocular micrometer.

\section{RESULTS}

In Iowa, $P$. camellifolia is restricted to gallery forests along major rivers, and colonies in central Iowa are disjunct from those of eastern Iowa $(150$ to $200 \mathrm{~km})$. In western Iowa, distribution of $P$. camellifolia is limited to two colonies, one in Waubonsie State Park in Fremont County (colony number 10), and another in a county park in Page County (colony number 11) (Fig. 1).

Table 1. Nested ANOVA. $\mathrm{A}=$ Subgenital plate length. $\mathrm{B}=$ Subgenital plate slit length. $\mathrm{C}=$ Pulse number per chirp.

\begin{tabular}{lrrc}
\hline Source & d.f. & \multicolumn{1}{c}{ MS } & $\begin{array}{c}\text { \% of total } \\
\text { variation }\end{array}$ \\
\hline A. Colonies & 14 & 34.33 & 87.33 \\
Individuals (Colonies) & 190 & 0.37 & 12.67 \\
\hline B. Colonies & 14 & 9.36 & 76.99 \\
Individuals & 190 & 0.21 & 23.01 \\
\hline C. Colonies & 19 & 1976.53 & 79.50 \\
Individuals (Colonies) & 191 & 34.39 & 14.52 \\
Records (Individuals Colonies) & 4009 & 0.69 & 5.98 \\
\hline
\end{tabular}

All characters showed significant $F$ values (ranging from 2.54 to $74.02, \mathrm{p} \leq .01$ ). However, of the 11 morphological and behavioral parameters measured, only subgenital plate length (SPL), subgenital plate slit length (SPSL) and number of pulses per chirp (P/C) showed greater variation between colonies than within colonies (Table 1). Also these three characters were the only ones by which the colonies were separated into two significantly different populations by the Duncan's multiple range test (Table 2). SPSL is not shown in Table 2 
because the groups delineated by this character were the same as by SPL. For population diagnosis, SPL would be simpler to measure than SPSL.

Duncan's test for $\mathrm{P} / \mathrm{C}$ delineates the same two groups (Table 3 ) as analysis of SPL (Table 2). However, in the former case, additional colonies are included in both groups because specimens were not collected from all colonies. Western katydids, those with long subgenital plates (colonies 1-10; Table 2), produce long chirps (colonies 1-11; Table 3). In contrast, northern katydids, those with short subgenital plates (colonies 12-16), produce short chirps (colonies 12-20).

Table 2. Duncan's multiple range test for variable SPL (subgenital plate length). Means with the same letter and overlapping ranges of means designated by two or more letters are not significantly different. The range of means designated $F$ are significantly different from overlapping range of means designated A, B, C, D and E (p $<.05)$.

\begin{tabular}{cccc}
\hline $\begin{array}{c}\text { Colony } \\
\text { number }\end{array}$ & N & Mean \pm sd $(\mathrm{mm})$ & Grouping \\
\hline 4 & 11 & $17.2 \pm .5$ & A \\
2 & 25 & $16.8 \pm .6$ & B A C \\
3 & 23 & $16.6 \pm .6$ & B P C \\
9 & 4 & $16.4 \pm .2$ & B D C \\
5 & 35 & $16.4 \pm .8$ & D C \\
10 & 42 & $16.3 \pm .5$ & D C \\
1 & 9 & $16.2 \pm .5$ & D C \\
7 & 4 & $15.8 \pm .6$ & E D C \\
6 & 7 & $15.2 \pm .3$ & E D \\
8 & 5 & $15.1 \pm .2$ & E \\
16 & 5 & $13.0 \pm .5$ & F \\
13 & 8 & $13.0 \pm .5$ & F \\
12 & 11 & $12.9 \pm .4$ & F \\
15 & 6 & $12.4 \pm .2$ & F \\
14 & 10 & $12.2 \pm .3$ & F \\
\hline
\end{tabular}

All 40 males collected from colonies believed to be members of the northern population have cerci the ventral arms of which bifurcate with dorsal and ventral arms pointed distally (Fig. 2A). In contrast, 135 of 165 males from the western population showed a slightly bifurcate, blunt ventral cercal arm (Fig. 2B). The remaining 30 males exhibited various cercal shapes (e.g., Figs. 2C and 2D), making them indistinguishable regarding population affiliation. 
The ranges of population means for the distance from the frons to the distal end of the tegmina (western: $38.3-44.7 \mathrm{~mm}$; northern: $37.4-39.7 \mathrm{~mm}$ ), frons to distal end of subgenital plate (western: 35.7-38.6 mm; northern: $31.7-33.7 \mathrm{~mm}$ ), tegminal length (western: 32.8-37.9 mm; northern: $31.4-33.7 \mathrm{~mm}$ ), metathoracic femoral length (western: 17.9-20.6 mm; northern: 13.0-15.1 mm), and tegminal width (western: 13.7-15.1; northern: 13.0-15.1), indicate that western katydids are on the average larger than northern katydids (North 1978).

\section{Discussion}

Iowa is the northwestern limit of the range of $P$. camellifolia. The distribution of oak-hickory forests, even in presettlement times, eliminates the availability of much of the western and northern part of the state (Fig. 1). Approximately $75 \%$ of the 6.5 million acres of woodland that greeted the state's first white settlers in the 1850's has been destroyed, leaving a sparse 1.6 million acres. Temperature also may be an important factor in limiting the northward extension of $P$. camellifolia south of available oak-hickory forest (Fig. 1). The same factors appear to affect the distribution of 17-year cicadas whose northern limits in Iowa mimic those of $P$. camellifolia even though suitable habitat is also available for range expansion of this species (Lloyd and Dybas 1966).

At the time of the original land survey in Iowa territory, the native vegetation was of two main types, prairie and deciduous forest. More than three-quarters of the state was open grassland and the remainder oak-hickory forest (Simonson et al. 1952). Since Caucasians arrived in Iowa, the removal of timber has been extensive. It is possible that in presettlement times $P$. camellifolia was more or less continuously distributed across eastern and southern Iowa. However, our failure to find any colonies between southwest and central Iowa (Fig. 1) argues against such a continuous distribution.

The western and northern populations of $P$. camellifolia may have differentiated during the Pleistocene. Deevey (1949) concluded that glacial chilling was so extensive that many species of plants and animals could have survived only in peninsular Florida and in Mexico. The existence of four or more populations of $P$. camellifolia in the eastern half of the United States (Hebard 1941, Alexander 1968, Shaw and Carlson 1969), as well as dispersion by flightless females argues against only these two glacial refugia. 
Transeau (1941), Braun (1951), and Thomas (1951) believe that preglacial forests and associated animals have existed throughout the Pleistocene in the Allegheny Plateau within a short distance of the glacial boundary. Kemp (1979) suggests that the present distribution pattern of the primitive flightless Grylloblatta in western Canada was derived from stock that survived the Pleistocene glaciation relatively close to the glacial front, and that migration routes from Wyoming and Montana permitted refugium populations to reach their present locations. Alexander and Moore (1962) argue convincingly that periodical cicada populations survived in approximately their present locations. They believe the last glacial advance resulted in brood splitting of 17-year cicadas with the populations closest to the glacial border separating from their more southern members because of diapause summation resulting from repeated periods of exposure to

Table 3. Duncan's multiple range test for variable $\mathrm{P} / \mathrm{C}$ (pulse number per chirp). Means with the same letter and overlapping ranges of means designated by two or more letters are not significantly different. The range of means designated $F$ are significantly different from overlapping range of means designated $\mathrm{A}, \mathrm{B}, \mathrm{C}, \mathrm{D}$ and $\mathrm{E}$ (p $<.05$ ). ${ }^{*}=$ colonies from which specimens have been collected (see Table 2).

\begin{tabular}{cccc}
\hline $\begin{array}{c}\text { Colony } \\
\text { number }\end{array}$ & $\mathrm{N}$ & Mean \pm sd & Grouping \\
\hline $1^{*}$ & 11 & $13.6 \pm 2.9$ & $\mathrm{~B} \mathrm{~A}$ \\
$3^{*}$ & 20 & $9.4 \pm 1.9$ & $\mathrm{~B}$ \\
$9^{*}$ & 10 & $9.4 \pm 1.8$ & $\mathrm{~B} \quad \mathrm{C}$ \\
$5^{*}$ & 10 & $8.5 \pm 1.4$ & $\mathrm{~B}$ D C \\
$8^{*}$ & 10 & $7.6 \pm 0.7$ & $\mathrm{D} \mathrm{C}$ \\
$4^{*}$ & 10 & $7.5 \pm 1.1$ & $\mathrm{D} \mathrm{C}$ \\
$2^{*}$ & 10 & $7.5 \pm 1.7$ & $\mathrm{D} \mathrm{C}$ \\
11 & 10 & $7.4 \pm 0.9$ & $\mathrm{E} \mathrm{D}$ \\
$10^{*}$ & 10 & $6.7 \pm 0.6$ & $\mathrm{E} \mathrm{D}$ \\
$7^{*}$ & 10 & $6.6 \pm 0.9$ & $\mathrm{E}$ \\
$6^{*}$ & 10 & $6.1 \pm 1.7$ & $\mathrm{~F}$ \\
20 & 10 & $3.7 \pm 0.5$ & $\mathrm{~F}$ \\
19 & 10 & $3.6 \pm 0.6$ & $\mathrm{~F}$ \\
18 & 10 & $3.5 \pm 0.5$ & $\mathrm{~F}$ \\
$14^{*}$ & 10 & $3.3 \pm 0.6$ & $\mathrm{~F}$ \\
$13^{*}$ & 10 & $3.3 \pm 0.6$ & $\mathrm{~F}$ \\
$15^{*}$ & 10 & $3.0 \pm 0.4$ & $\mathrm{~F}$ \\
$12^{*}$ & 10 & $2.9 \pm 0.6$ & $\mathrm{~F}$ \\
17 & 10 & $2.8 \pm 0.7$ & $\mathrm{~F}$ \\
$16^{*}$ & 10 & $2.5 \pm 0.5$ &
\end{tabular}


A

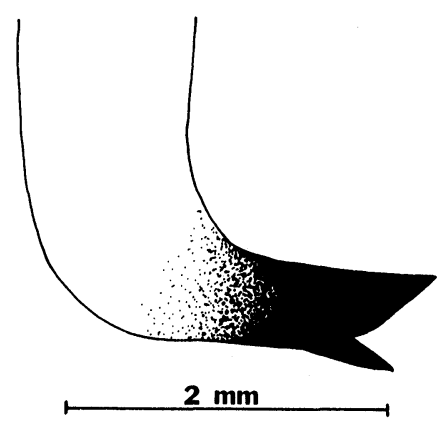

C

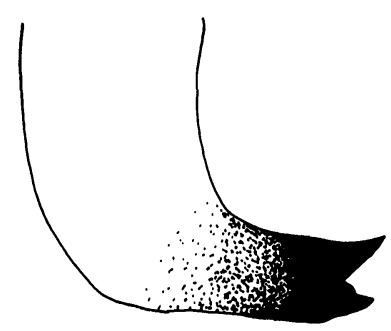

B

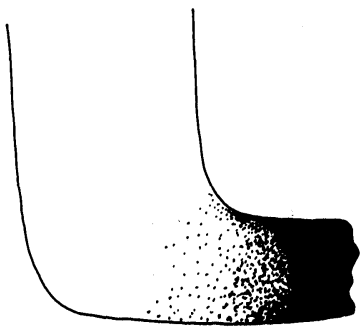

D

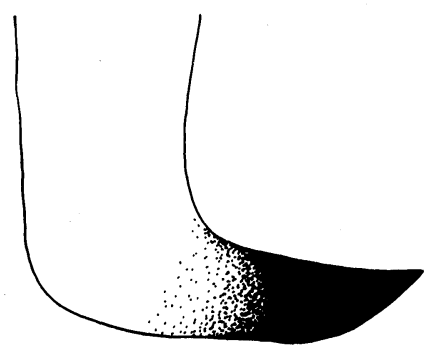

Fig. 2. Ventral arm of male cercus, ventral view. A. Northern population, colony \#10. B. Western population, colony \#3. C. Western population, colony\#4. D. Western population, colony \#5.

extreme cold. Such a brood-splitting could have resulted in brood III (central and southeast Iowa) and brood IV (southwest Iowa and south to Texas).

Smith (1957) takes a position intermediate to that of Deevy (1949) and that proposed by Transeau (1941), Braun (1951), Thomas (1951), and Alexander and Moore (1962). Smith's evidence is principally southern disjunct, relict populations of boreal vertebrates whose main contemporary distributions lie "partially or wholly within glaciated North America". These relict populations, widely separated from the main segment of their species ranges, occur in such states as Missouri, Arkansas, Kansas, Tennessee, and Georgia.

Such western (Missouri, Arkansas, Kansas) and eastern (Tennessee, Georgia) separation of a preglacial population of $P$. camellifolia could have been responsible for differentiation of the western and 
northern populations of this species. Examination of subgenital plates and cercal arms of 12 specimens from Anderson County, Kansas, indicate they are western $P$. camellifolia. This would support Kansas as a possible glacial refuge and site of differentiation of western $P$. camellifolia.

Postglacial northern migration of oak-hickory forests with their accompanying fauna along the rivers of the Missouri and Mississippi drainage systems would have facilitated contact between western and northern katydids. Forest continuity in southern Iowa could have allowed the western population to cross from the Missouri to the Mississippi drainage system. During the Climatic Optimum Period (warm, moist period from approximately 6000-8000 B.P.), deciduous forest occurred more continuously and at slightly higher latitudes than at present (Smith 1957). Southward and eastward shrinking of the ranges of fauna and flora may have occurred during the warm and dry Hypsithermal (= Xerothermic Interval, ca. 4000-6000 B.P.) (Smith 1957). On the basis of the Climatic Optimum Period and boreal relicts, Smith argues for gallery forests or "islands" of forests along the major rivers as refugia for mesic-forest-inhabiting animals during this period. Although the drier-loving oak-hickory forests may have at first advanced during this period, they probably receded later and again may have remained only as gallery forests along rivers.

Assuming that the western and northern populations had come together during the Climatic Optimum Period, their present distribution could be explained by the effects of the Hypsithermal. The western and northern populations occur along or near river systems where they could have escaped the extreme conditions of the Hypsithermal. This could explain the existence of both western and northern populations within the Wisconsin drift area (Fig. 1), an area which contains protected ravines created by the actions of the Wisconsin glacier. The main bodies of these two populations could have been pushed southwestward and east-southeastward. The 150-200 $\mathrm{km}$ gaps between the southwestern and central colonies of western katydids and the eastern and central colonies of northern katydids could simply be the result of lack of forest and/or time to renew contact.

The fragmentation of animal ranges resulting from the activities of civilized man throughout his historic period has resulted in many 
relict populations (Smith 1965). Such fragmentation facilitates population differentiation. As for $P$. camellifolia, fragmentation is most effective at the periphery of their range where habitat and animals are climatically limited. P. camellifolia in Iowa consists of a number of relatively small isolated colonies which are undergoing morphological and behavioral differentiation (a remarkable example is western colony \#1 [Table 3] within which some males produce up to 30 pulses/chirp) and which may eventually become reproductively isolated populations.

The intrapopulation variation of colonies of western and northern $P$. camellifolia could be a result of 1) inbreeding of small isolated populations, and/or 2) gene exchange between formerly continuous western and northern populations. Further field studies are necessary to determine the extent of the distribution of the western and northern populations outside Iowa. Crossing experiments as well as choice and non-choice phonataxis experiments, involving playbacks of calling sounds to virgin females of both populations, are necessary for a decision regarding the taxonomic affinity of northern and western $P$. camellifolia.

\section{ACKNOWLEDGMENTS}

We wish to thank Dr. D. F. Cox, Department of Statistics, Iowa State University, for assistance with the statistical analysis, and Dr. R. E. Lewis, Department of Entomology, Iowa State University, for reviewing the manuscript. Special thanks are due Ms Patti Hanson for prodigious assistance in the survey and the collection of specimens.

\section{Literature Cited}

AleXander, R. D. 1956. A comparative study of sound production in insects, with special reference to the singing Orthoptera and Cicadidae of the eastern United States. Ph.D. Dissertation. Ohio State University. 529 pp.

Alexander, R. D. 1968 . Arthropods. In T. A. Sebeok, ed. Animal communication, pp. 167-216. Indiana University Press, Bloomington, Ind.

Alexander, R. D. And T. E. Moore. 1962. The evolutionary relationships of 17year and 13-year cicadas, and three new species (Homoptera, Cicidadae, Magicicada). Misc. Publ. Mus. Zool. Univ. Michigan 121:1-59.

Beutenmuller, W. 1894. Descriptive catalogue of the Orthoptera found within fifty miles of New York City. Bull. Amer. Mus. Nat. Hist. 6: 316 pp.

Blatchley, W. S. 1903. The Orthoptera of Indiana. 27th Ann. Rep. Ind. Dept. of Geol. and Nat. Resources. Indianapolis, Ind. 471 pp. 
Blatchley, W. S. $1920 . \quad$ Orthoptera of Northeastern America. Nature Publ. Co., Indianapolis, Ind. $784 \mathrm{pp}$.

Braun, E. L. 1951. Plant distribution in relation to the glacial boundary. Ohio J. Sci. 51:139-146.

BUrmeister, H. 1838. Handb. Ent., II-Orthoptera. Berlin. 697 pp.

Caudell, A. N. 1906. The Cyrtophylli of the United States. J. N. Y. Entomol. Soc. 14:32-45.

Deevey, E. S. 1949. Biogeography of the Pleistocene. Part I, Europe and North America. Geol. Soc. Amer. Bull. 60:1315-1416.

FABRICIUS, J. C. 1775. Systema entomologiae sistens insectoium, synonymis, locis, descriptionibus, observationibus. Flensburgi et Lipsiae. $832 \mathrm{pp}$.

Fowells, H. A. 1965. Silvics of forest trees of the United States. U. S. Dept. Agr. Handb. 271. 762 pp.

FroesChNeR, R. C. 1954. The grasshoppers and other Orthoptera of Iowa. Iowa State J. Sci. 29:163-354.

Hebard, M. 1941. The group Pterophyllae as found in the United States (Tettigoniidae: Pseudophyllinae). Trans. Amer. Entomol. Soc. 67:197-220.

Kemp, J. W. 1979. Taxonomy, distribution, and zoogeographic evolution of Grylloblatta in Canada (Insecta: Notoptera). Can. Entomol. 111:27-38.

Kirby, W. AND W. SPENCE. 1828. Introd. Ent. 5th ed. London. 607 pp.

KIrby, W. 1906. Syn. Cat. Orth. II. Orthoptera Saltatoria, Pt. I. London. 562 pp.

Lloyd, M. AND H. S. Dybas. 1966. The periodical cicada problem. II. Evolution. Evolution 20(4):466-505.

NorTh, R. C. 1978. Pterophylla camellifolia (Fabricius) (Orthoptera: Tettigoniidae) in Iowa: Variation in distribution, morphology and calling song. Master's Dissertation. Iowa State University. $39 \mathrm{pp}$.

Rehn, J. A. G. AND M. Hebard. 1916. Studies in the Dermaptera and Orthoptera of the coastal plain and Piedmont region of the southwestern United States. Proc. Acad. Nat. Sci. Phil. 68:187-338.

Shaw, K. C. AND O. V. Carlson, 1969. The true katydid, Pterophylla camellifolia (Fabricius) (Orthoptera: Tettigoniidae) in Iowa: two populations which differ in behavior and morphology. Iowa State J. Sci. 44:193-200.

Shaw, R. W. And P. J. Waite. 1964. The climate of Iowa. Iowa State Univ. of Sci. and Tech. Agr. and Home Econ. Exp. Sta. Special Report No. 38.

Simonson, R. W., Gichen, F. F. And G. D. Smith. 1952. Understanding lowa soils. W. C. Brown Co., Dubuque, Iowa.

Sмiтh, R. W. 1957. An analysis of post-Wisconsin biogeography of the prairie peninsula region based on distributional phenomena among terrestrial vertebrate poulations. Ecology 38(2):205-218.

Sмітн, R. W. 1965. Recent adjustments in animal ranges. In H. E. Wright and D. G. Frey, eds. The Quaternary of the United States, pp. 633-642. Princeton Univ. Press, Princeton, New Jersey.

Thомas, E. S. 1951. Distribution of Ohio animals. Ohio J. Sci. 51:153-167.

Transeau, E. N. 1941. Prehistoric factors in the development of the vegetation of Ohio. Ohio J. Sci. 41:207-211.

Walden, B. H. 1911. The Euplexoptera and Orthoptera of Connecticut. Connecticut State Geol. and Nat. Hist. Surv. Bull. No. 16. 169 pp. 

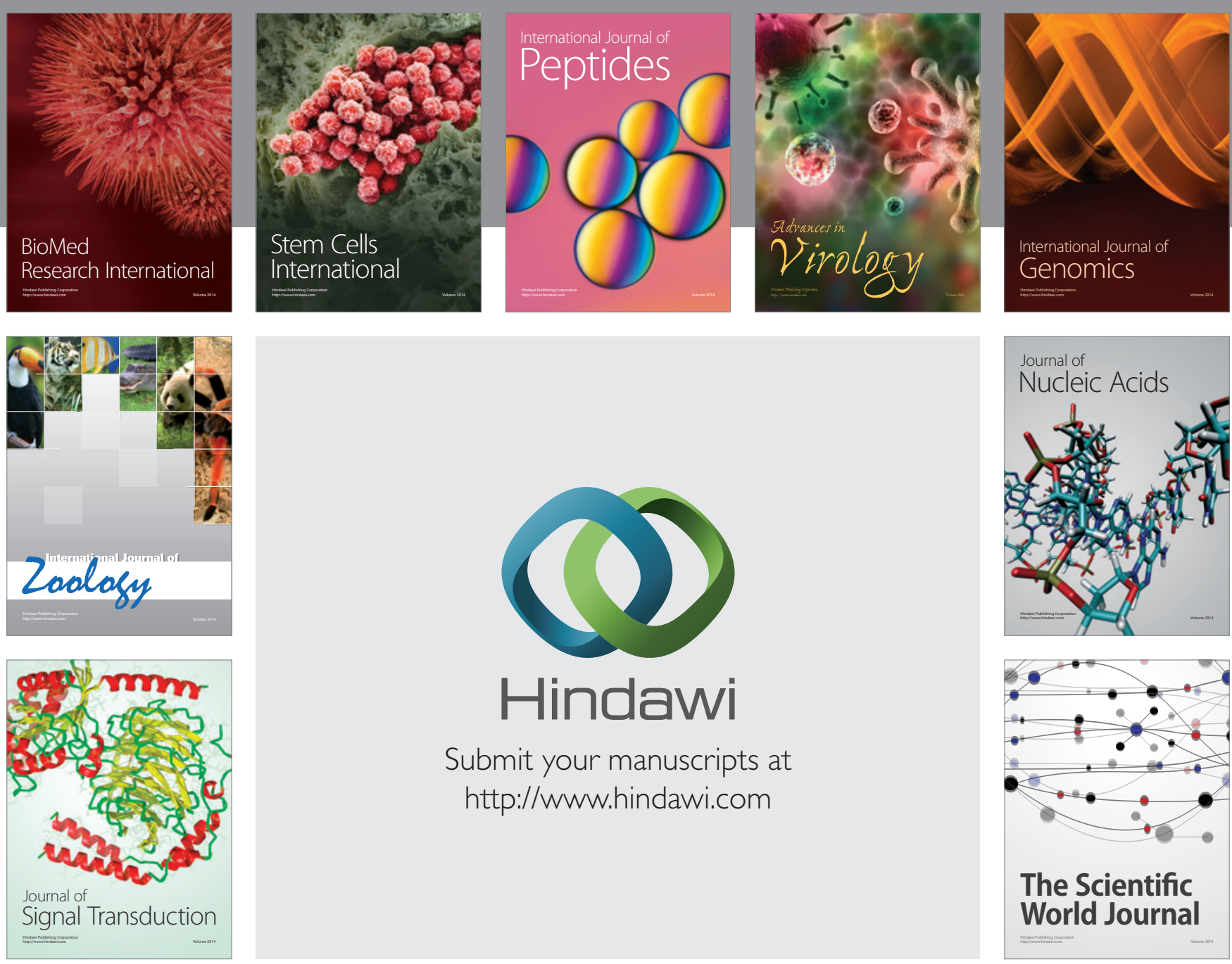

Submit your manuscripts at

http://www.hindawi.com
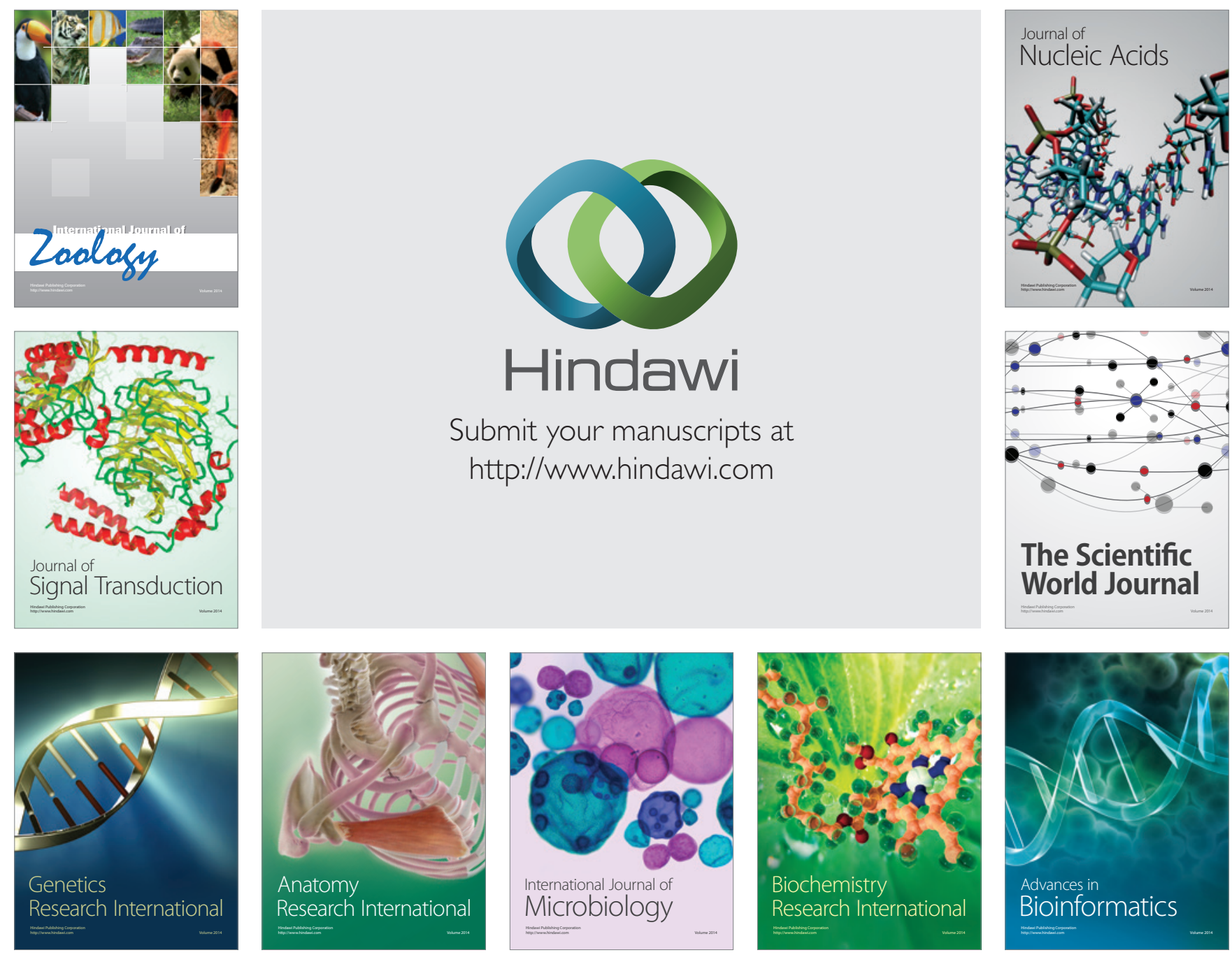

The Scientific World Journal
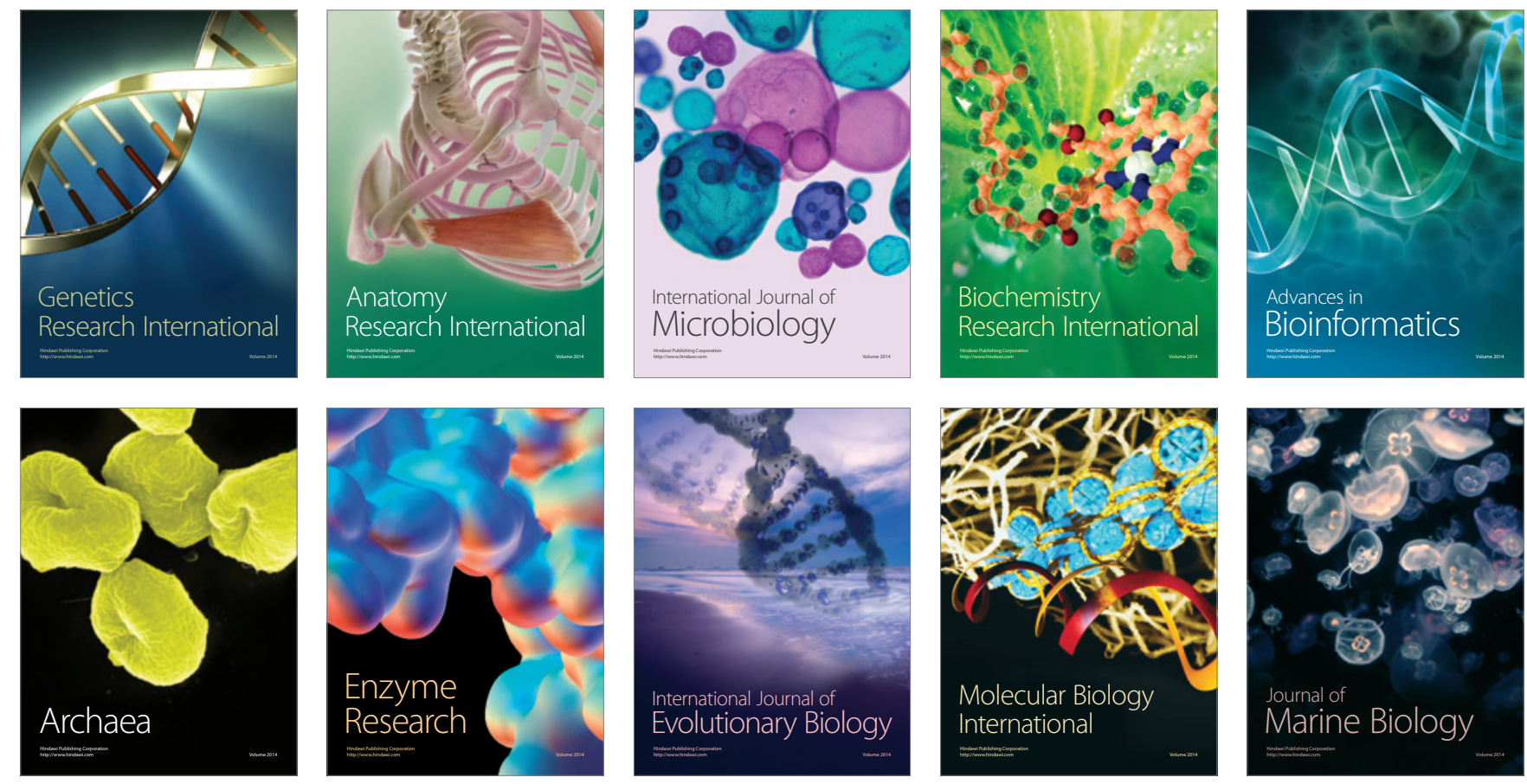